\title{
Detection of Bartonella quintana DNA in the presence of human and feline whole blood by single-tube PCR without DNA extraction
}

\author{
Bridget Ann Morton and Pedro Paulo Vissotto de Paiva Diniz* \\ *Correspondence: pdiniz@westernu.edu \\ Western University of Health Sciences, College of Veterinary Medicine, 309 East Second Street, Pomona, California, 91766, USA.
}

\begin{abstract}
Background: Rapid and cost-effective detection of emerging zoonotic blood-borne pathogens, such as Bartonella spp., is important for diagnostic and surveillance purposes. DNA extraction is a tedious process that increases the risk of cross-contamination, decreases the amount of target nucleic acids, and increases costs. The concept of using a direct PCR protocol for the detection of Bartonella in the presence of whole feline or human blood without DNA extraction was evaluated.

Findings: An optimized, single-tube, direct PCR for the detection of B. quintana in the presence of 20\% of EDTA whole blood was optimized and validated using a DNA polymerase resistant to common PCR inhibitors. Ten genome equivalents of $B$. quintana/ $\mu$ l of blood were detected $100 \%$ of the time, and 2 genome equivalents/ $\mu \mathrm{l}$ were detected $91 \%$ of the time.

Conclusions: The direct PCR for the detection of Bartonella quintana in whole blood is a viable, quick, highly sensitive, and costeffective alternative that deserves further exploration.
\end{abstract}

Keywords: 16S-23S ribosomal RNA intergenic transcribed spacer, Alphaproteobacteria, Bartonellosis, Diagnosis, Direct PCR

\section{Introduction}

Nucleic acid amplification via polymerase chain reaction $(P C R)$ is a well-established and highly sensitive tool for the molecular detection of pathogenic organisms from blood, tissues, and other clinical samples in humans and animals. Typically, highly purified template DNA is required for adequate gene amplification. However, a wide range of proteins, ionic detergents, organic solvents, alcohols, and salts can decrease or even inhibit polymerase activity $[\mathbf{1 , 2}]$. Clinical samples such as whole blood and other specimens contain various PCR inhibitors. In whole blood, these inhibitors may be natural components such as heme, immunoglobulins, and leukocyte DNA, or added anticoagulants such as EDTA and heparin [1-3].

In order to decrease the presence of PCR inhibitors, multiple DNA extraction techniques have been developed and extensively tested. Although these methods have various advantages, they also present many disadvantages such as being labor intensive, time consuming, sample specific, and sometimes costly. In addition, they may decrease the detectable amount of target nucleic acids, increase the risk of cross-contamination between samples, and even introduce exogenous DNA from contaminated reagents [1-3]. Therefore, several protocols for nucleic acid amplification without previous purification of nucleic acids (direct PCR) have been published for the detection of virus, bacteria, protozoan, fungi, animal, or human genetic material [4-6]. However, to the knowledge of the authors, no direct PCR has been designed and validated for the detection of intraerythrocytic tick-borne diseases in humans, due to the presence of PCR inhibitors in whole blood.

Bacteria of the genus Bartonella are fastidious, gram-negative, aerobic bacilli that are mainly transmitted by insect bites, such as fleas, ticks, and sand flies. Bartonella causes a long-lasting intraerythrocytic bacteremia in humans and other mammals and is considered an emerging zoonotic pathogen [7]. In humans, organisms from this genus are the causative agents of bacillary angiomatosis, endocarditis, myocarditis, cat scratch disease, intraocular inflammation, and recently have been associated with progressive neurological disease [7-9]. Domestic cats can be infected with several species of Bartonella, including $B$. henselae, B. clarridgeiae, B. koehlerae, B. quintana, and B. bovis. Cats are able to directly transmit the infection to humans by bites and scratches $[7,10]$.

Diagnosis of intracellular pathogens that maintain chronic infections are typically detected via one or more diagnostic procedures, such as bacterial isolation, enzyme-linked immunosorbent assay (ELISA), immunofluorescence assay (IFA), or PCR amplification [7,11]. However, antibody detection has limited diagnostic value in humans and animals because infected subjects frequently lack antibody response to Bartonella spp. $[12,13]$. Culture remains the gold-standard for laboratory diagnosis of Bartonella; however, over two months of culture may be required, due to the slow-growth characteristic of these organisms [14]. Among numerous PCR assays described for Bartonella species, very few have used direct PCR amplification, and none has directly targeted this organism in blood samples without DNA extraction steps. Bartonella direct PCR was only reported twice, from heart valve vegetations [15] and from synovial fluid [4]. In addition, Bartonella spp. have been detected in healthy blood donors [16], and can survive in stored blood for over 35 days [17], suggesting a potential for transfusion- 
Morton et al. Microbiology Discovery 2013,

associated infection. However, the use of direct PCR for the detection of Bartonella spp. from blood samples from humans and animals has not yet been explored.

Due to the diagnostic challenges faced when attempting to detect Bartonella spp. from EDTA-blood and the disadvantages of the DNA extraction process, this study aimed to test the concept of using direct PCR for the detection of Bartonella quintana from human and feline blood as a rapid molecular diagnosis method of Bartonellosis.

\section{Materials and methods}

\section{Bartonella quintana isolate and negative controls}

B. quintana strain ND1 (GenBank accession number DQ648598) isolated from a woman after putative cat bite transmission [18] was used as positive control in order to mimic the natural infection in both species. Purified and quantified DNA of this strain was serially diluted to concentrations of 500 genome equivalents $(\mathrm{GE}) / \mu \mathrm{l}, 50 \mathrm{GE} / \mu \mathrm{l}, 10 \mathrm{GE} / \mu \mathrm{l}, 5 \mathrm{GE} / \mu \mathrm{l}$, and $1 \mathrm{GE} / \mu \mathrm{l}$, aliquoted in multiple vials and kept at $-30^{\circ} \mathrm{C}$. Each dilution was tested 11 times in the presence of feline whole blood or human whole blood. No single vial of each dilution was frozen and thawed more than five times to prevent DNA degradation. EDTA-blood from a healthy human and asymptomatic cat were used as negative controls.

\section{Conventional 16S-23S ribosomal RNA intergenic transcribed spacer (ITS) PCR}

A previously published conventional PCR assay designed to amplify the $16 \mathrm{~S}-23 \mathrm{~S}$ ribosomal RNA ( $r R N A$ ) intergenic transcribed spacer (ITS) of Bartonella species [11] was used to rule-out natural Bartonella infection in both human and feline blood negative controls prior to artificial inoculation with quantified amounts of Bartonella DNA. In order to prevent contamination, DNA extraction, reaction setup, PCR amplification, and amplicon detection were performed in separate areas. This conventional PCR assay was able to detect $50,25,10$, and $5 \mathrm{GE}$ of $B$. quintana per reaction tube $100 \%$ of the time.

\section{Blood direct PCR conditions and variables tested}

A commercially available kit (Phusion B Blood Direct PCR Kit, Finnzymes, Finland) was used. The following variables were tested in combination to determine the most sensitive and reproducible results: total PCR reaction volumes of $20 \mu \mathrm{l}$, $25 \mu \mathrm{l}$, and $50 \mu \mathrm{l}$; whole blood concentrations of $5 \%, 10 \%$, $20 \%, 25 \%, 30 \%$, and $40 \%$; primer concentration from 7.5 pmol to $25.5 \mathrm{pmol} ; \mathrm{MgCl}_{2}$ gradients of $3 \mu \mathrm{M}, 4 \mu \mathrm{M}$, and 4.5 $\mu \mathrm{M}\left(50 \mathrm{mM}\right.$ of $\mathrm{MgCl}_{2}$ solution); and $2.5 \mu \mathrm{l}$ of $100 \%$ DMSO (in $50 \mu \mathrm{l}$ total reaction volume). Primers targeting the $16 \mathrm{~S}-23 \mathrm{~S}$ rRNA ITS described above [11] were used for blood direct PCR. Amplifications were performed under the following conditions: one cell lysis cycle at $98^{\circ} \mathrm{C}$ for 5 minutes; followed by 55 cycles of denaturing at $98^{\circ} \mathrm{C}$ for 5 seconds; annealing for 20 seconds; and extension at $72^{\circ} \mathrm{C}$ for 20 seconds. The
Table 1. Optimal conditions and analytical sensitivity of direct PCR amplification of Bartonella quintana DNA in whole blood from humans and cats.

\begin{tabular}{|c|c|}
\hline Component & $25 \mu \mathrm{l}$ reaction \\
\hline $\mathrm{H}_{2} 0$ & $5.8 \mu \mathrm{l}$ \\
\hline 2x PCR buffer ${ }^{*}$ & $12.5 \mu \mathrm{l}$ \\
\hline Primer ITS $438 \mathrm{~s}(30 \mathrm{mM})$ & $0.35 \mu \mathrm{l}$ \\
\hline Primer ITS 1000as (30 mM) & $0.35 \mu \mathrm{l}$ \\
\hline DNA polymerase $^{+}$ & $0.35 \mu \mathrm{l}$ \\
\hline $\mathrm{MgCl}_{2}(50 \mathrm{mM})$ & $1 \mu \mathrm{l}$ \\
\hline Whole blood & $5 \mu \mathrm{l}(20 \%)$ \\
\hline \multicolumn{2}{|l|}{ Primer annealing temperature } \\
\hline Human blood & $68^{\circ} \mathrm{C}$ \\
\hline Feline blood & $67^{\circ} \mathrm{C}$ \\
\hline \multicolumn{2}{|l|}{ Analytical sensitivity } \\
\hline $50 \mathrm{GE} /$ reaction $^{\ddagger}-10 \mathrm{GE} / \mu \mathrm{l}$ of human or feline blood ${ }^{\S}$ & $100 \%(11 / 11)$ \\
\hline $10 \mathrm{GE} /$ reaction $\left(2 \mathrm{GE} / \mu \mathrm{l}\right.$ of human or feline blood $\left.{ }^{\S}\right)$ & $90.9 \%(10 / 11)$ \\
\hline $5 \mathrm{GE} /$ reaction $(1 \mathrm{GE} / \mu \mathrm{l}$ of feline blood $)$ & $45.5 \%(5 / 11)$ \\
\hline $5 \mathrm{GE} /$ reaction $(1 \mathrm{GE} / \mu \mathrm{l}$ of human blood $)$ & $36.4 \%(4 / 11)$ \\
\hline
\end{tabular}

${ }^{\star}$ Phusion ${ }^{\circledast}$ Blood PCR Buffer (includes dNTPs and $3 \mathrm{mM} \mathrm{MgCl}_{2}$ ) $\dagger$ Phusion ${ }^{\circledast}$ Blood II DNA Polymerase

$\ddagger$ Genome equivalents of $B$. quintana per PCR reaction tube $\S$ Eleven replicates were tested for each host blood (human or feline)

annealing temperature was tested at $66^{\circ} \mathrm{C}, 67^{\circ} \mathrm{C}$, and $68^{\circ} \mathrm{C}$ in a thermocycler with a maximum sample ramp rate of $3.35^{\circ} \mathrm{C}$ per second (Verity ${ }^{\circledR}$ Thermal Cycler, Applied Biosystems, Life Technologies Corp. Carlsbad, CA). One microliter of each quantified dilution of $B$. quintana DNA was used as positive control. Molecular grade water was used as negative control. B. quintana amplicons were identified with approximately $377 \mathrm{bp}$ in size by $2 \%$ agarose gel electrophoresis under UV exposure. Non-spiked human and feline blood were used as negative controls.

\section{Results}

Optimized conditions with the best analytical sensitivity results for blood direct PCR are provided (Table 1). Bartonella DNA was amplified in the presence of $5 \%, 10 \%$, and $20 \%$ of whole blood, but not in the presence of $40 \%$. Therefore, $20 \%$ was established as the targeted concentration of blood for the optimization of sensitivity. Serial dilutions of B. quintana in EDTA-blood were detected at concentrations of $50 \mathrm{GE}$ per reaction $100 \%$ of the time in 11 replicates of human whole blood, as well as 11 replicates of feline whole blood; $10 \mathrm{GE}$ per reaction were detected $90.9 \%$ (10 out of 11 replicates) of the time in both human and feline blood; $5 \mathrm{GE}$ per reaction were detected $45.5 \%$ ( 5 out of 11 replicates) of the time in feline blood, and $36.4 \%$ (4 out of 11 replicates) of the time in human blood. Since $5 \mu \mathrm{l}$ of whole blood were added in each reaction tube, the analytical sensitivity for a naturallyinfected blood sample was $10 \mathrm{GE} / \mu \mathrm{l} 100 \%$ of the time, with the limit of detection of $1 \mathrm{GE} / \mu \mathrm{l}$ (Figure 1). No amplifications were obtained from negative controls in any condition tested. 


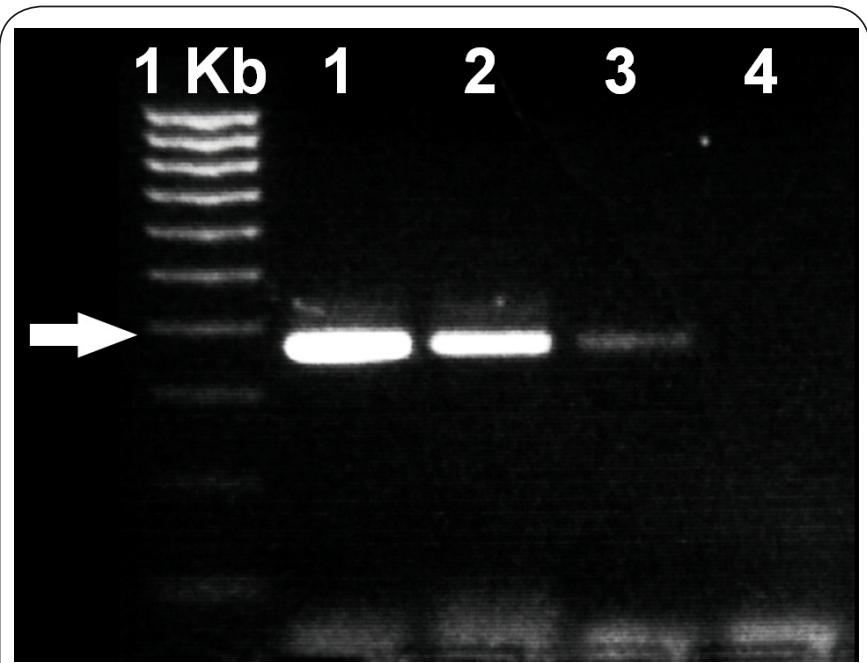

Figure 1. Direct PCR of Bartonella quintana 16S-23S rRNA intergenic spacer region in the presence of $20 \%$ of human whole blood. Lane $1=50$ genome equivalents per reaction; lane $2=$ 10 genome equivalents; lane $3=5$ genome equivalents; lane 4 = negative control (water). Molecular marker: $1 \mathrm{~Kb}$. The arrow indicates $400 \mathrm{bp}$.

\section{Discussion}

This study demonstrates the ability of direct PCR to detect Bartonella DNA in the presence of human or feline blood without DNA extraction and purification. The commercial kit used in this study employs a modified hot-start, high-fidelity DNA polymerase that exhibits extremely high resistance to inhibitors found in blood. A wide range of blood concentrations, from $1 \%$ to $40 \%$, can be used with this kit. Since the detection of low numbers of targeted DNA per reaction is directly related with the volume of whole blood added in a direct PCR reaction, the optimization of this assay was designed to use the maximum amount of blood that would not significantly interfere with analytical sensitivity, determined to be $20 \%$ for this direct PCR assay. The analytical sensitivity achieved with this direct PCR assay was surprisingly close to that obtained from conventional PCR using the same ITS primers used in this study [11]. The natural infection of Bartonella spp. in immunocompetent humans causes an average bacteremia level of 1 to $10 \mathrm{GE} / \mu \mathrm{l}$ of whole blood, while in infected cats it is estimated to be between $10^{5}$ to $10^{6} \mathrm{GE} / \mu \mathrm{l}[7]$. Therefore, the analytical sensitivity of 2 to 10 copies/ $\mu$ l of blood obtained with the direct PCR assay in this study supports the use of this diagnostic test for both species. Other conventional Bartonella PCR assays have reported detection limits between 2 and 50 genome equivalents $[13,14,19,20]$. Using the same direct PCR kit from this study, Fuehrer et al., (2011) described the detection of 3 to $5 \mathrm{GE}$ of Plasmodium spp. from dried blood samples in filter paper [5]. Therefore, the results of this study are in line with the analytical sensitivity obtained by conventional PCR assays, suggesting that the direct PCR can be a quick and costeffective alternative for the diagnosis of Bartonella infection.
The cost effectiveness of blood direct PCR has been recently described [5]; however, in that report the direct PCR was used only in the first step of a nested PCR using $50 \mu \mathrm{l}$ of reaction volume in each step. Because nested PCR has an intrinsically higher risk of cross-contamination [19] and uses twice as many reagents per tested sample, this approach was not used in our study. Our study achieved successful amplifications by using only a single step direct PCR with only $25 \mu$ l of reaction volume, resulting in consequent economy of reagents. The extended number of cycles used in this study provided sufficient analytical sensitivity without interfering with the specificity of the amplification, as previously reported with other DNA polymerases $[11,13]$.

Bartonella species may be present in blood or other clinical samples in concentrations below the limit of detection of molecular techniques [12,18]. A Bartonella Alpha Proteobacteria Growth Medium (BAPGM) was designed to multiply the number of targeted organisms prior to PCR amplification and/or isolation in culture plates [14].However, liquid culture samples with high concentration of Bartonella organisms need to be subjected to laborious DNA extraction, increasing the chances of cross-contamination. The direct PCR assay described in this study may also be used for fast screening of liquid cultures after the enrichment process without the need for DNA extraction.

Despite proving the concept of detecting very low numbers of Bartonella DNA in the presence of whole blood, this study has several limitations. Red blood cells with intracellular Bartonella spp. were not used due to the technical challenges of obtaining erythrocytes infected with these organisms in vitro, and precisely quantifying the number of genome equivalents in whole blood without DNA extraction. The quantification of colony-forming units (CFU) from blood spiked with a Bartonella isolate was not an option in this study due to the fastidious nature of these organisms and their sub-optimal growth in solid media cultures. The use of quantified DNA based on the molecular weight of the fully sequenced $B$. quintana genome provided an accurate quantification of genome equivalents used in this study, as previously reported $[11,13]$. Because ITS primers used in this study were originally designed to amplify multiple Bartonella species, it is expected that the direct PCR assay reported here would be able to accurately detect other species of Bartonella. However, additional studies are needed to evaluate the efficacy of the direct PCR in detecting other Bartonella species, not only in human and feline blood, but also other mammalian species.

The results of this study indicate that direct PCR from blood is a viable, rapid, highly sensitive, and cost effective alternative for the diagnosis of Bartonella spp. without a DNA extraction step. The use of highly-resistant polymerases for the detection of Bartonella andother intracellular organisms, not only in blood but also in other diagnostic specimens, deserves further investigation. 
Morton et al. Microbiology Discovery 2013,

\section{List of abbreviations}

BAPGM: Bartonella Apha Proteobacteria Growth Medium

CFU: colony-forming unit

GE: genome equivalent

IFA: immunofluorescence assay

ITS: intergenic transcribed spacer

Kb: kilobase

PCR: polymerase chain reaction

rRNA: ribosomal RNA

UV: ultraviolet light

\section{Competing interests}

The authors declare that they have no competing interests.

\section{Authors' contributions}

PPVPD conceived and designed the study, and helped to draft the manuscript. BAM carried out laboratory experiments and wrote the manuscript. Final manuscript was read and approved by both authors.

\section{Acknowledgement}

DNA from B. quintana was kindly provided by Edward B. Breitschwerdt and Ricardo G. Maggi, from the Intracellular Pathogens Research Laboratory at North Carolina State University. This study was supported by Western University of Health Sciences (WesternU). Bridget Morton was supported by a summer fellowship from WesternU. Blood direct PCR kits were kindly provided by New England BioLabs Inc., Ipswich, MA, which did not participate in the study design, data collection, analysis, conclusions, or generation of this manuscript. The authors thank John R. Greenwood for critical review of the manuscript and for administrative support.The authors also thank Maryam Tngrian, Dominique Griffon and Steven Henriksen for support at various levels at WesternU.

\section{Publication history}

Received: 21-Feb-2013 Revised: 22-Mar-2013

Accepted: 10-Apr-2013 Published: 03-May-2013

\section{References}

1. Al-Soud WA and Radstrom P: Purification and characterization of PCRinhibitory components in blood cells. J Clin Microbiol 2001, 39:485-93. | Article | PubMed Abstract | PubMed Full Text

2. Radstrom $P$, Knutsson $R$, Wolffs $P$, Lovenklev $M$ and Lofstrom C: PrePCR processing: strategies to generate PCR-compatible samples. Mol Biotechnol 2004, 26:133-46. | Article | PubMed

3. Wilson IG: Inhibition and facilitation of nucleic acid amplification. App/ Environ Microbiol 1997, 63:3741-51. | Pdf | PubMed Abstract | PubMed Full Text

4. Dillon B, Cagney M, Manolios N and Iredell JR: Failure to detect Bartonella henselae infection in synovial fluid from sufferers of chronic arthritis. Rheumatol Int 2000, 19:219-22. | Article | PubMed

5. Fuehrer HP, Fally MA, Habler VE, Starzengruber P, Swoboda P and Noedl $\mathrm{H}$ : Novel nested direct PCR technique for malaria diagnosis using filter paper samples. J Clin Microbiol 2011, 49:1628-30. | Article | PubMed Abstract | PubMed Full Text

6. Li H, Xu H, Zhao C, Sulaiman Y and Wu C: A PCR amplification method without DNA extraction. Electrophoresis2011, 32:394-397. | Article

7. Breitschwerdt EB, Maggi RG, Chomel BB and Lappin MR: Bartonellosis: an emerging infectious disease of zoonotic importance to animals and human beings. J Vet Emerg Crit Care 2010, 20:8-30. | Article | PubMed

8. Breitschwerdt EB, Mascarelli PE, Schweickert LA, Maggi RG, Hegarty BC, Bradley JM and Woods CW: Hallucinations, sensory neuropathy, and peripheral visual deficits in a young woman infected with Bartonella koehlerae. J Clin Microbiol 2011, 49:3415-7. | Article | PubMed Abstract I PubMed Full Text
9. Jacomo V, Kelly PJ and Raoult D: Natural history of Bartonella infections (an exception to Koch's postulate). Clin Diagn Lab Immunol 2002, 9:818. | Article | PubMed Abstract | PubMed Full Text

10. Chomel BB, Boulouis HJ, Maruyama S and Breitschwerdt EB: Bartonella spp. in pets and effect on human health. Emerg Infect Dis 2006, 12:38994. | Article | PubMed Abstract | PubMed Full Text

11. Cherry NA, Maggi RG, Rossmeisl JH, Hegarty BC and Breitschwerdt EB: Ecological diversity of Bartonella species infection among dogs and their owner in Virginia. Vector Borne Zoonotic Dis 2011, 11:1425-32. | Article | PubMed

12. Breitschwerdt EB, Maggi RG, Robert Mozayeni B, Hegarty BC, Bradley JM and Mascarelli PE: PCR amplification of Bartonella koehlerae from human blood and enrichment blood cultures. Parasit Vectors 2010, 3:76. | Article | PubMed Abstract | PubMed Full Text

13. Diniz PP, Maggi RG, Schwartz DS, Cadenas MB, Bradley JM, Hegarty B and Breitschwerdt EB: Canine bartonellosis: serological and molecular prevalence in Brazil and evidence of co-infection with Bartonella henselae and Bartonella vinsonii subsp. berkhoffii. Vet Res 2007, 38:697-710. | Article | PubMed

14. Maggi RG, Duncan AW and Breitschwerdt EB: Novel chemically modified liquid medium that will support the growth of seven bartonella species. J Clin Microbiol 2005, 43:2651-5. | Article | PubMed Abstract | PubMed Full Text

15. Qin $X$ and Urdahl KB: PCR and sequencing of independent genetic targets for the diagnosis of culture negative bacterial endocarditis. Diagn Microbiol Infect Dis 2001, 40:145-9. | Article | PubMed

16. Magalhaes RF, Cintra ML, Barjas-Castro ML, Del Negro GM, Okay TS and Velho PE: Blood donor infected with Bartonella henselae. Transfus Med 2010, 20:280-2. | Article | PubMed

17. Magalhaes RF, Pitassi LH, Salvadego M, de Moraes AM, Barjas-Castro ML and Velho PE: Bartonella henselae survives after the storage period of red blood cell units: is it transmissible by transfusion? Transfus Med 2008, 18:287-91. | Article | PubMed

18. Breitschwerdt EB, Maggi RG, Sigmon B and Nicholson WL: Isolation of Bartonella quintana from a woman and a cat following putative bite transmission. J Clin Microbiol 2007, 45:270-2. | Article | PubMed Abstract | PubMed Full Text

19. Apfalter P, Reischl U and Hammerschlag MR: In-house nucleic acid amplification assays in research: how much quality control is needed before one can rely upon the results? J Clin Microbiol 2005, 43:5835-41. | Article | PubMed Abstract | PubMed Full Text

20. Hagege AA, Caudron E, Damy T, Roudaut R, Millaire A, EtchecoparChevreuil C, Tran TC, Jabbour F, Boucly C, Prognon P, Charron P and Germain DP: Screening patients with hypertrophic cardiomyopathy for Fabry disease using a filter-paper test: the FOCUS study. Heart 2011, 97:131-6. | Article | PubMed

\section{Citation:}

Morton B and Diniz PP: Detection of Bartonella quintana DNA in the presence of human and feline whole blood by single-tube PCR without DNA extraction. Microbiology Discovery 2013, 1:7. http://dx.doi.org/10.7243/2052-6180-1-7 